UDK $551.351 .2+474.2+261.35$

Jaan LUTT*, Priit TAMMIK**

\title{
TALLINNA LAHE PÕHJASETTED
}

Tallinna lahe põhi on kaetud mitmesuguse vanusega setenditega. Väheldaste laikudena paljanduvad kambriumi settekivimid, mõnevõrra laiemalt esinevad moreen, hilis- ja pärastjääaegsed järvesavid. Ulatusliku levikuga on jäänukmoodustised, mis katavad vanemaid setteid ōhukese, sageli ebapüsiva kihina. Nüüdissetteist on madalaveelisemail aladel ulatuslikud mitmesuguse terajämedusega liivad, sügavamal aga aleuriidid ja peliidid. Stabiilse sedimentatsiooniga alad vahelduvad seaduspäraselt kulutus- ja transiidialadega, kusjuures viimased on mōningases ülekaalus.

Lõimiseanalüüsi põhjal selgub, et vaadeldavad setted on üsnagi ebaühtlase koostisega, põhifraktsioonide sisaldus on suhteliselt madal ning lisandfraktsioonide osatähtsus kõrge.

Tallinna lahte piirab idast Viimsi poolsaar, lõunast manner, mere poolt aga Naissaar ja Âegna saar. Laht on avatud põhja- ja läänekaare tuultele, talle on iseloomulikud suured sügavused (Aegna ja Naissaare vahel üle $90 \mathrm{~m}$ ), üsnagi järsud nõlvad (kohati $2-3^{\circ}$ ) ning väljavenitatus loode-kagu suunas. Tavaliselt käsitatakse Tallinna lahena kitsamas mõttes (nn. Tallinna reid) Paljassaare ja Viimsi poolsaare vahelist ala, kuna laiema käsituse korral kuuluvad siia ka Paljassaare, Kopli ja Kakumäe e. Tiskre laht. Lääneosas on Tallinna laht ühendatud Soome lahega Suurupi väina, põhjas aga Naissaare ja Aegna vahelise laia väinaga. Tallinna laht on üks Eesti põhjarannikule tüüpilisi klindilahti ning siinse nüüdissedimentatsiooni seaduspärasused kehtivad ka naberlahtedes. Lahte ümbritsev maismaa on intensiivse inimtegevuse mõju all ning seetõttu on tema põhjasetete igakülgsel tundmaõppimisel lisaks teaduslikule ka praktiline tähtsus. Tallinn produtseerib märkimisväärsel hulgal loodusele vaenulikke jääkprodukte, mis suures osas heidetakse merre. Tundmata sedimentatsiooni seaduspärasusi ning kulgu ei ole võimalik kontrollida kahjulike komponentide liikumist ja ladestumist.

Käesolevas kirjutises on esitatud ülevaade Tallinna lahe (laiemas käsituses) põhjasetete pindmisest kihist. See võimaldab saada ettekujutuse siinsetest settekuhjumisprotsessidest. Kasutatud materjal on kogutud aastate jooksul Eesti Teaduste Akadeemia Geoloogia Instituudi ja Eesti Geoloogiakeskuse meregeoloogide poolt. Esmajärjekorras on tähelepanu pööratud setete leviku ja struktuursete omaduste (lõimise) väljaselgitamisele, kuna just lõimise järgi toimub setete klassifitseerimine ning seega on lõimis ka settekaartide koostamise aluseks. Kogutud materjali põhjal saab ülevaate erinevate settetüüpide levikust ja vahekorrast ning võib kindlaks määrata piirkonnad, kus toimub põhja kulutus või settematerjali stabiilne kuhjumine. Esitatud põhjasetete kaardi (joon. 1) koostamisel on kasutatud rohkem kui 130 haardkopaga võetud põhjaproovi, mis paigutuvad ühtlaselt kogu akvatooriumi ulatuses.

Tallinna lahe piires saab eristada nelja erineva vanusega setendirühma. Väga vähese pindalaga laikudena on siin otse merepõhjas vanala dekonda kuuluvaid kambriumi settekivimeid (joon. 1). Viimased on tavaliselt kaetud õhukese $(1-2 \mathrm{~cm})$ ebastabiilse liivakihiga, mis teatud juhtudel, näiteks tugeva lainetuse puhul võib ära kanduda. Mõnevõrra ulatuslikuma levikuga on pleistotseense vanusega moreen ning hilis- ja

\footnotetext{
* Eesti Teaduste Akadeemia Geoloogia Instituut. EE0105 Tallinn, Estonia pst. 7. Estonia.

** Eesti Geoloogiakeskus, EE0102 Tallinn, Pikk 67, Estonia,
} 


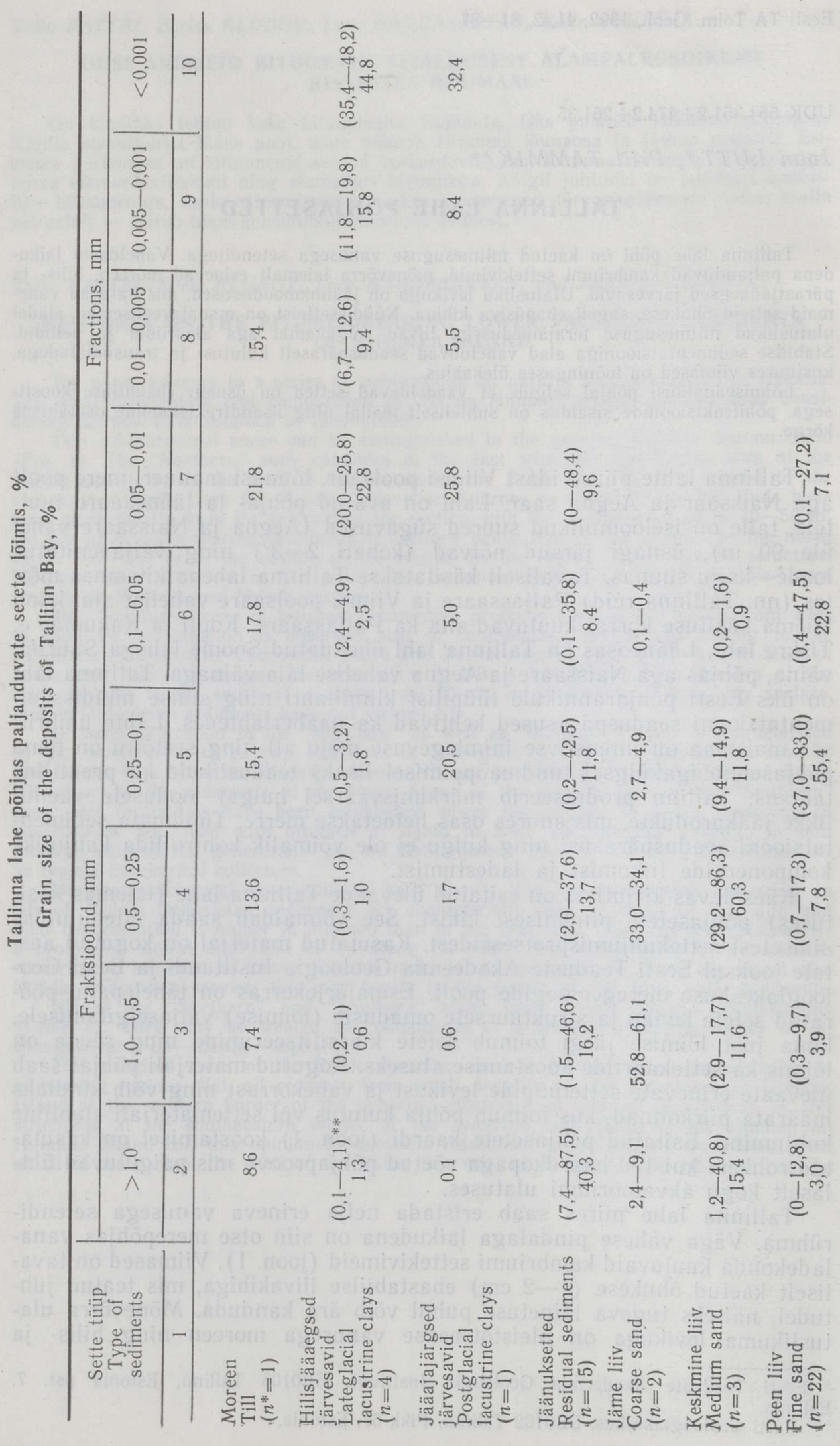




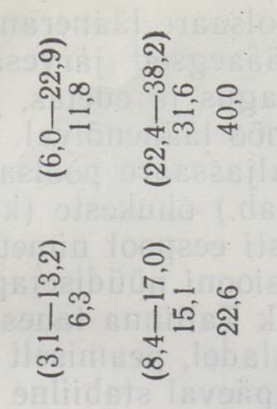

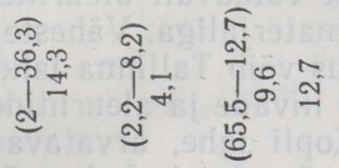

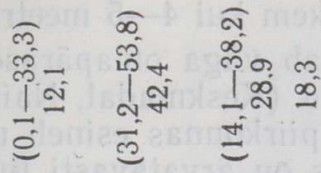

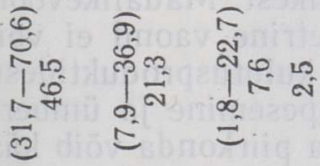

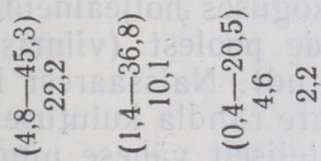

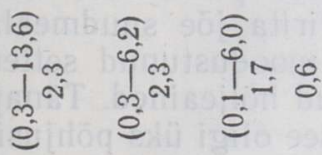

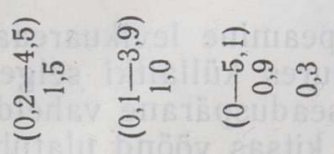

离

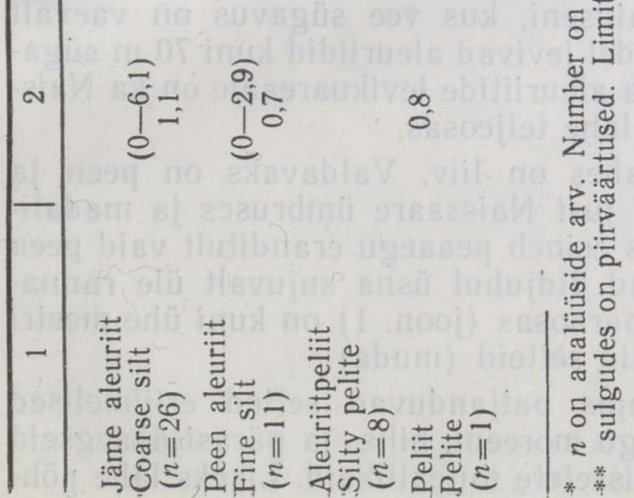


pärastjääaegsed järvesetted: moreen Viimsi poolsaare läänerannakul ning Kopli poolsaare veealusel pikendusel, hilisjääaegsed järvesavid Kopli lahes, Haabneeme lähistel ning Naissaarest kagus ja edelas, jääajajärgsed järvesavid lahe teljeosas kulgeva sügava nõo läänenõlval. Laiad alad Aegna ümbruses, Suurupi väinas, Kopli ja Paljassaare poolsaare rannakul on kaetud üsna heterogeense koostisega (tab.) õhukeste (kuni $10 \mathrm{~cm}$ ) jäänuksetetega (joon. 1), mis katavad enamasti eespool nimetatud vanemaid setteid. Need alad kujutavad sedimentatsiooni nüüdisetapil kulutusja transiidipiirkondi ning siit pärinebki enamik Tallinna lahes akumuleeruvast mineraalsest settematerjalist. Suurtel aladel, peamiselt lahe sügavamas teljeosas ning lahepärades toimub tänapäeval stabiilne setete kuhjumine (joon. 1, 2). Esimesel juhul on tegemist valdavalt aleuriitsete ja peliitsete, teisel juhul aga aleuriitse või liivase materjaliga. Väheste puursüdamike põhjal saab öelda, et meresetete paksus võib Tallinna lahes olla väga erinev. Näiteks Pirita jõe suudmealal võib liivade ja aleuriitide paksus ulatuda 5-6 meetrini, samal ajal aga Kopli lahe, arvatavasti ka Kakumäe lahe päraosas tõenäoliselt mitte üle 2 meetri: Lahe sügavas teljeosas võib peente meresetete paksus olla rohkem kui 4-5 meetrit.

Nüüdissedimentatsiooni seisukohast moodustab väga omapärase piirkonna Naissaarest itta jääv madalaveeline vöönd (Keskmadal, Naissaare madal, Littegrund ja teised madalikud). Selles piirkonnas esineb ulatuslikum liiva levikuareaal, kusjuures liiva allikaks on arvatavasti liustikujõgede setted, mis moodustavad enamiku madalikest. Madalikevööndit ja Naissaart lahutav suhteliselt sügav, 24-29-meetrine vaond ei võimalda sellel alal toituda Naissaare idapoolse randla kulutusproduktidest ning seega toimub siin vaid pidev settematerjali läbipesemine ja ümberpaigutumine, ilma et settemass oluliselt muutuks. Seda piirkonda võib käsitlèda omapärase suletud süsteemina, kuhu ei lisandu settimisvõimelist materjali, ent kust ei kanta ka ära märkimisväärses koguses hõljeaineid, kuna siinsed liivad on vaesed peenemate koostisosade poolest (viimased on pideva läbipesemise tagajärjel sügavamale kantud). Naissaarest lõunas jälgitav liivaareaal (joon. 1) toitub enamasti saare randla kulutusel moodustuvast settematerjalist. Lahtede päraosa suhteliselt vähese pindalaga liivaalad toituvad enamasti poolsaarte veealuste pikenduste kulutusel moodustuvast materjalist. Erandi moodustab Pirita jõe suudmeala, kus lisaks Viimsi poolsaare rannaku kulutusaladel moodustunud settematerjalile kogunevad ka Pirita jõe poolt merre kantud hõljeained. Tänapäeval on viimaste osatähtsus tunduvalt vähenenud ja see oligi üks põhjusi, miks Pirita supelranna edasiseks säilitamiseks oli vaja tuua juurde liiva (kunstliku ranna loomine).

Peenemate, aleuriitsete ja peliitsete setete peamine levikuareaal kulgeb Tallinna lahe sügavamas teljeosas, kusjuures küllaltki selgesti on jälgitav erineva terajämedusega settevööndite seaduspärane vaheldumine sügavuse suurenedes. Peliitide (aleuriitpeliidi) kitsas vöönd ulatub kitsa tsentraalse vööndina Paljassaare laiuseni, kus vee sügavus on vaevalt 40 meetrit. Samal ajal kesknõo nõlvadel levivad aleuriidid kuni 70 m sügavuseni. Mõnevõrra vähema pindalaga aleuriitide levikuareaale on ka Naissaarest ida pool, Kopli ja Kakumäe lahe teljeosas.

Levinud settetüübiks Tallinna lahes on liiv. Valdavaks on peen ja keskmine liiv, vähemal määral, eriti just Naissaare ümbruses ja madalikel on ka jämedat liiva. Lahepärades esineb peaaegu eranditult vaid peen liiv, kusjuures rannakusetted lähevad üldjuhul üsna sujuvalt üle rannaliivadeks. Vaid Kopli lahe äärmises päraosas (joon. 1) on kuni ühe meetri sügavuseni peliitseid orgaanikarikkaid setteid (muda).

Lõimiselt on Tallinna lahe põhjas paljanduvad setted eriilmelised (tab.), kusjuures vanemaid neist, nagu moreeni, hilis- ja pärastjääaegseid järvesetteid tuleb vaadelda kui nüüdissețetẹ toiteallikaịd. Lisaks lahe põh- 


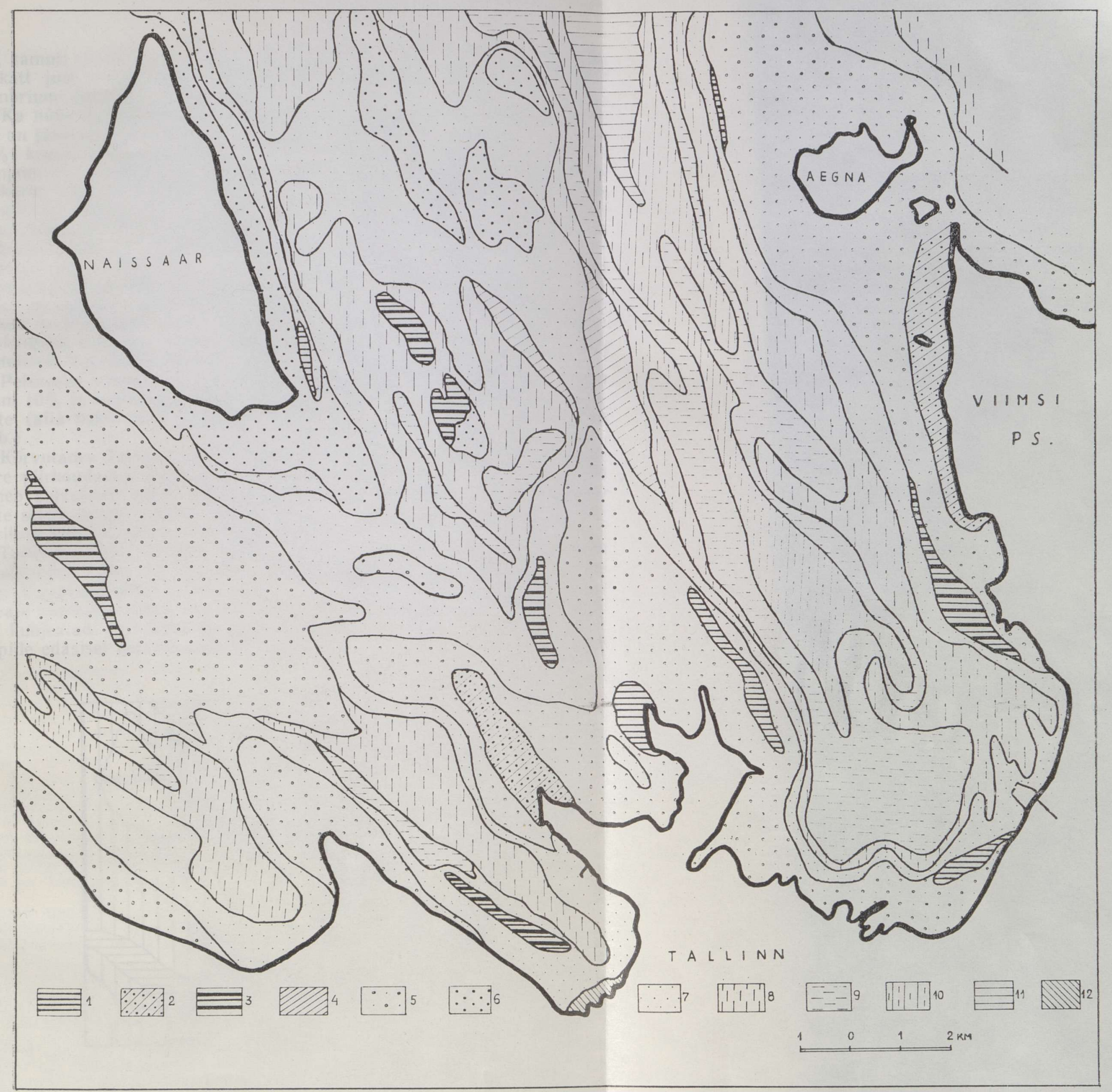

Joon. 1. Setendid Tallinna lahe põhjas, 1 - kambriumi settekivimid, 2 - moreen, 3 - hilisjääaegsed järvesavid, 4 - jääajajärgsed järvesavid; 5 12 - nüüdissetted: 5 - jäänuksetted, 6 - keskmine ja jäme liiv, 7 - peen liiv, 8 - jäme aleuriit, $9-$ peen aleuriit, $10-$ aleuriitpeliit, $11-$ peliit, 12 - peeneteralised orgaanikarikkad setted (muda).

Fig. 1. Settlements of Tallinn Bay, 1 - Cambrian sedimentary rocks, 2 - till, 3 - lateglacial lacustrine clays, 4 - postglacial lacustrine clays; 5 12 - modern sediments: 5 - residual deposits on the late- and postglacial deposits, 6 - coarse and medium sand, 7 - fine sand, 8 - coarse silt, 9 fine silt, 10 - silty pelite, 11 - pelite, 12 - pelitic sediments enriched with organic matter (mud). 
jas, samuti rannal kulutatavaile kvaternaarisetteile on küllaltki oluliseks, eeskätt just liivafraktsioonide allikaks Kakumäe ja Suurupi poolsaare kambriumi liivakivide paljandid.

$\mathrm{Ka}$ nüüdisaegsete meresetete lõimis on eripalgeline. Väga heterogeensed on jäänuksetted. Neis, eriti moreenil lasuvais, on sageli ülekaalus (üle $80 \%$ ) kruusa ja veeriste fraktsioonid. Mõningail juhtudel võib ka aleuriitse komponendi sisaldus neis ületada $40 \%$. Stabiilsete kuhjealade jämeda ja keskmise liiva iseloomustamiseks on esialgu veel vähe andmeid, kuid olemasolevate põhjal (tab.) võib öelda, et tegu on üsnagi ühtlase materjaliga, milles üle $80 \%$ liivafraktsioone $(1-0,1 \mathrm{~mm})$. Tunduvalt rohkem on andmeid peenliiva kohta. Vaadeldaval alal on mitmesuguse sorteeritusastmega peent liiva, kuid ülekaalus on hästi sorteeritud erimid, milles jämedamaid lisandeid on harva üle $10-15 \%$, mõnevõrra rohkem (15$20 \%$ ) on aga aleuriitset lisandit. Tallinna lahe aleuriitsed setted on suhteliselt lisandirikkad (tab.). Võrreldes näiteks hästi uuritud Väinamere analoogsete setetega (Лутт, 1985), on siin olulisem eeskätt liivalisand, suhteliselt tagasihoidlikum on peenemate komponentide osatähtsus.

Peliitseist setteist on enam levinud aleuriitpeliit, milles on sageli palju (kuni $10 \%$ ja rohkemgi) liivalisandeid. Iseloomulik on subkolloidsete osakeste (alla $0,001 \mathrm{~mm}$ ) stabiilne domineerimine peliidifraktsiooni hulgas (tab.).

Kõrvutades Tallinna lahe nüüdissetete lõimist teistest Eesti rannikumere piirkondadest kogutud analüütilise materjaliga võib öelda, et siin esineb suhteliselt palju liivakomponente, ja seda eriti lisandina peenemate setete hulgas. Setete sorteeritus ei ole eriti kõrge ja harva on sorteerituse koefitsiendi $S_{0}$ väärtus alla 1,5 .

Tallinna lahele on iseloomulik seaduspärane kulutus- ja kuhjealade vaheldumine (joon. 2), kusjuures valdavaiks on esimesed. Mõnede suuremate kulutusareaalide piires, näiteks Aegna ümbruses, Naissaarest idas olevate madalike vahel, samuti Suurupi väinas esinevad lokaalselt püsivad kuhjealad. Tervikuna on setete levikupilt mosaiikne ja muutub settetüüpide edasisel detailiseerimisel veelgi keerukamaks. Suuremad stabiilse

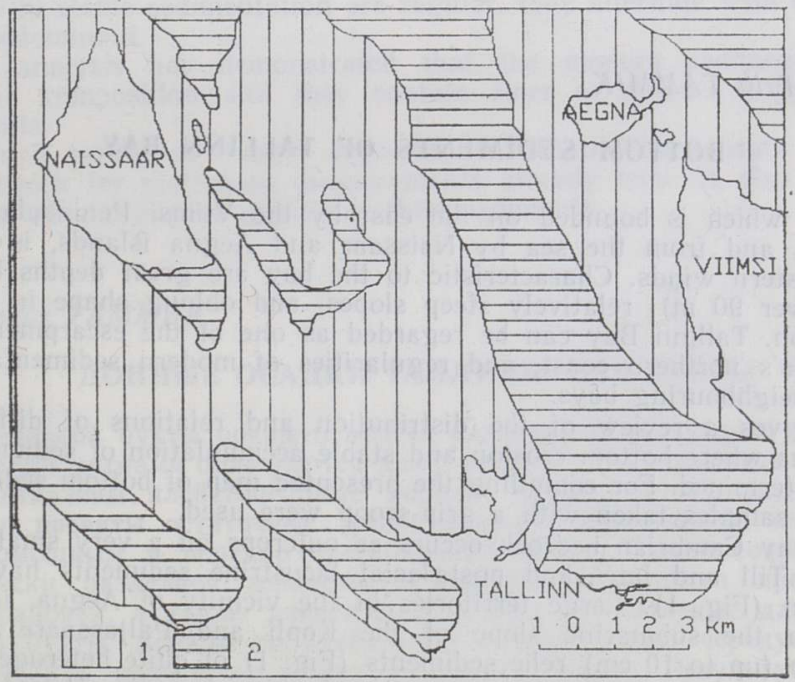

Joon. 2. Kuhje- ja kulutus (transiidi) alade paiknemine Tallinna lahes. 1 - valdab kulutus, 2 - valdab kuhje.

Fig. 2. Modern sedimentation in Tallinn Bay. 1 - areas with abrasion prevailing, $2-$ areas with accumulation prevailing. 
sedimentatsiooniga alad on Kakumäe ja Kopli lahe teljeosas, ka piki lahe keskmist osa kulgevas nõos. Vähemad stabiilse settimisega piirkonnad on jälgitavad ka Naissaare ümbruses. Neile piirkondadele on omased enamasti peenemad, aleuriitsed ja peliitsed setted. Liivad on stabiilsete kuhjealade piires jälgitavad vaid randla piires, eeskätt lahtede päraosas.

Esitatud ülevaade lahe põhjasetteist võimaldab juba praegu kindlaks määrata uurimisvõrgu statsionaarsete mõõtmiste tarvis, samuti kavandada nende setete igakülgseks tundmaõppimiseks vajaliku uurimistöö metoodika.

Ulaltoodust tulenevalt on vaja silmas pidada järgmisi põhimomente: - Tallinna lahes levivad ulatuslikult vanade setenditega piirkonnad, kus nüüdissetted kas puuduvad või on esindatud õhukese jäänuksetete kihiga; - nüüdissetted, s. o. niisugused setted, mille kujunemine toimub tänapäevastes füüsilis-geograafilistes ja hüdroloogilistes tingimustes, on madalamates piirkondades esindatud peamiselt liivadega, sügavamal toimub järkjärguline üleminek aleuriitideks ja peliitideks, seega kogunevad $\mathrm{ka}$ loodusvaenulikud ained, mis enamasti assotsieeruvad savikomponendiga, sügavamates piirkondades;

- püsiva sedimentatsiooniga alad vahelduvad kulutusaladega, kusjuures pindalaliselt on mõningases ülekaalus viimased;

- lõimiseanalüüsi põhjal on käsitletud akvatooriumi setted ebaühtlase koostisega ja sisaldavad lisaks põhifraktsioonile märgatavas koguses jämedamaid või peenemaid lisandeid.

\section{KIR J AN DUS}

Лутт Я. 1985. Донные осадки Вяйнамери. Таллинн, Валгус, $238 \mathrm{lk}$.

Esitanud A. Raukas
Toimetusse saabunud 28. XI 1991

Jaan LUTT and Priit TAMMIK

\section{BOTTOM SEDIMENTS OF TALLINN BAY}

Tallinn Bay, which is bounded on the east by the Viimsi Peninsula, on the south by the mainland, and from the sea by Naissaar and Aegna islands, is opened to the northern and western winds. Characteristic to the bay are great depths between Aegna and Naissaar (over $90 \mathrm{~m}$ ), relatively steep slopes, and oblong shape in the northwestsoutheast direction. Tallinn Bay can be regarded as one of the escarpment (glint) bays typical of Estonia's northern coast, and regularities of modern sedimentation are valid also in case of neighbouring bays.

The paper gives a review of the distribution and relations of different types of sediments; regions where bottom erosion and stable accumulation of sedimentary material take place are determined. For compiling the presented map of bottom sediments (Fig. 1) over 130 bottom samples taken with a grip-scoop were used.

In Tallinn Bay Cambrian bedrock occurs as outcrops on a very small area right at the sea bottom. Till and late- and postglacial lacustrine sediments have a somewhat wider distribution (Fig. 1). Large territories in the vicinity of Aegna, in the Strait of Suurupi, and on the submarine slope of the Kopli and Paljassaare peninsulas are covered with thin (up to $10 \mathrm{~cm}$ ) relic sediments (Fig. 1) of quite heterogeneous composition (Table) lying mostly on the above-mentioned older deposits. These areas represent regions of erosion and transition in the modern stages of sedimentation and most of the depositional material accumulating in the Bay originates here. In the deeper axial part of the Bay and in the butt-ends stable accumulation of sediments takes place (Figs. 1 and 2). In the former areas mainly silty and pelitic material is involved, in the latter ones silty or sandy material. On the basis of a few drill-cores we can say that the thickness of the marine sediments in Tạllinn Bay may vary conșiderably. 
From the point of view of modern sedimentation, the region of shallows located east of Naissaar is a very peculiar area. In that region the largest distribution area of sand occurs; the source of the sand presumably is deposits of glacial rivers, which form most of the shoals. A relatively deep $(24-29 \mathrm{~m})$ hollow, isolating Naissaar from the shallow region, does not allow that area to have feeding from erosion processes of the eastern shore of Naissaar and so, only continuous rewashing of sedimentary material takes place here; the whole sedimentary mass is not changed substantially. The sand areas, observed south of Naissaar (Fig. 1), are fed mostly by sedimentary material formed in the course of the erosion of the shore of the island. In butt-ends of the bays, - sandy regions with relatively small areas are fed mainly by the material formed during the erosion of submarine prolongations of peninsulas. The estuary of the Pirita River is an exception. In addition to sedimentary material formed in the erosional areas of the shore of the Viimsi Peninsula, floating substance carried by the Pirita River to the sea has also accumulated. Today the importance of the floating substance has decreased considerably. This is one of the reasons why it has become necessary to bring additional sand to preserve the Pirita beach.

With regard to granulometry, the sediments occurring at the bottom of Tallinn Bay are quite different (Table). The older sediments like till and late- and postglacial lacustrine deposits should be regarded as a source of modern sediments. In addition to Quaternary deposits eroded at the bottom and on the shore, rather important sources for sand fractions are the outcrops of Cambrian sandstone on the Kakumäe and Suurupi peninsulas.

A comparison of the granulometric composition of the modern deposits of Tallinn Bay with analytical data gathered from other regions of the Estonian coastal sea shows that there are relatively many sand components here, especially as a supplement among finer sediments. The sorting of deposits is not very good and the coefficient of sorting, $S_{0}$, is above 1.5 .

Within certain larger erosional areas, for example those surrounding Aegna, between the shallows east of Naissaar, and also in the Strait of Surupi, regions with stable sedimentation occur at places. As a whole, the distribution pattern of sediments is rather mixed and mosaic-like.

Tallinn Bay, one of the spheres influenced by active human activities on the northern coast of Estonia, might become a model area for assessing the condition of the environment and interrelationships between man and the sea. Interesting theoretical and practical solutions can be expected as all necessary prerequisites for successful and operative research work are present here: research object - the bay with an intensive polluter (Tallinn) and explorers with versatile interests and the required equipment and experience.

In brief, the main characteristics of Tallinn Bay are:

- Large areas are covered with older sediments; in these areas modern sediments are absent or spread in thin layers.

- Modern sediments in deeper parts are mainly represented by silts or pelite and in shallow areas by sands.

- The areas with stable sedimentation are regular, they alternate with erosion areas, the latter being predominant.

- Grain size analysis has demonstrated that the modern sediments are relatively heterogenous in composition and they contain finer or coarser supplements in considerable amounts.

The presented survey of bottom deposits of Tallinn Bay permits to set down an exploration network for stationary measurements already now. It also enables to work out methods for all-round investigation of these sediments.

Яан ЛУТТ, Прийт ТАММИК

\section{ДОННЫЕ ОСАДКИ ТАЛЛИННСКОЙ БУХТЫ}

Дно Таллиннской бухты покрыто весьма различными по возрасту и составу осадками. Небольшими пятнами обнажаются даже кембрийские осадочные породы. Несколько шире представлены плейстоценовые морены, поздне- и послеледниковые озерные глины. Широко развиты остаточные (резидуальные) образования, покрывающие предыдущие маломощным и нередко нестабильным слоем. Среди современных осадков отмечаются пески различной зернистости, распространяющиеся преимущественно в мелководных районах, а также алевриты и пелиты, характерные для более глубоководных частей бухты. Ареалы со стабильной седиментацией чередуются с ареалами размыва и транзита, причем последних несколько больше. Результаты гранулометрического анализа показывают, что состав рассматриваемых осадков довольно гетерогенен: содержание определяющих фракций относительно низкое, а содержание соседних, примесных компонентов достаточно высокое. 